\title{
Value creation through peer communities of learners in an Egyptian context during the COVID-19 pandemic
}

\author{
Malak Zaalouk ${ }^{1} \cdot$ Heba EL-Deghaidy ${ }^{1} \cdot$ Lamiaa Eid $^{1} \cdot$ Lujain Ramadan $^{1}$
}

Published online: 27 April 2021

(c) UNESCO Institute for Lifelong Learning and Springer Nature B.V. 2021

\begin{abstract}
Like most education systems all over the world, Egypt's schools and universities turned to online teaching at the end of March 2020, after face-to-face classes had been brought to a halt by the outbreak of the COVID-19 pandemic. While few teachers were prepared for delivering their lessons online and for dealing with the stress and anxiety of the situation, this article showcases a group of teachers who had just acquired collaboration skills in peer communities of learners (PCLs), which proved to be an immediate source of support in this time of crisis. The authors present the results of a rapid study they conducted in June 2020 on a sample of 49 teachers from 17 schools in Egypt who had participated in a school-university partnership for reform. This included a continuous professional development (CPD) project which ran from February 2017 to March 2020. Within the project, these teachers had already successfully created PCLs in 43 schools partnering with faculties of education (FOEs) in three large Egyptian universities. The reform partnership, an ERASMUS+ initiative funded by the European Union (EU), was the "School University Partnership for Peer Communities of Learners" (SUP4PCL). By March 2020, the participating teachers had already significantly changed their teaching styles, school culture, identities and attitude towards their profession, and they continued to communicate with their peers in the PCLs they had created during the project. Prompted by the emergency situation of the pandemic and inspired by the work of Etienne Wenger and others on communities of practice, the authors' study investigates the sustainability, viability and effectiveness of the project PCLs, their relationship to lifelong learning and their value in offering psychosocial support. The article concludes with a consideration of the usefulness of PCLs for reforms to ensure quality learning in crisis situations and more generally.
\end{abstract}

Keywords school-university partnerships · peer communities of learners · communities of practice $\cdot$ COVID-19 - psychosocial support · value creation · lifelong learning

Malak Zaalouk mz@aucegypt.edu

Extended author information available on the last page of the article 


\section{Résumé}

Création de valeur par des communautés d'apprentissage entre pairs en Égypte pendant la pandémie de COVID-19 - Comme pour la plupart des systèmes d'éducation du monde entier, les écoles et universités égyptiennes se sont tournées fin mars vers l'enseignement en ligne, après que les cours en présentiel ont été interrompus à cause de la pandémie de COVID-19. Peu d'enseignants étaient préparés à faire cours en ligne et à affronter le stress et l'anxiété dans cette situation. Cet article présente un groupe d'enseignants qui venaient de se former à la collaboration dans des communautés d'apprentissage entre pairs, ce qui s'est immédiatement révélé être une source de soutien en cette période de crise. Les auteures présentent les résultats d'une étude rapide qu'elles ont menée en juin 2020 dans 17 écoles en Égypte auprès d'un échantillon de 49 enseignants qui avaient participé à un partenariat écoles-universités pour la réforme. Il comprenait un projet de développement professionnel continu qui s'est déroulé de février 2017 à mars 2020. Dans le cadre du projet, ces enseignants avaient déjà créé avec succès des communautés d'apprentissage entre pairs créé dans 43 écoles en partenariat avec les facultés de l'éducation de trois grandes universités égyptiennes. Le partenariat pour la réforme, une initiative ERASMUS+ financée par l'Union européenne, s'appelait Partenariat écoleuniversité pour les communautés d'apprentissage entre pairs (School University Partnership for Peer Communities of Learners-SUP4PCL). En mars 2020, les enseignants participants avaient déjà considérablement modifié leur style d'enseignement, leur culture scolaire et leurs identités et attitudes à l'égard de la profession, et ils continuaient de communiquer avec leurs pairs dans les communautés d'apprentissage qu'ils avaient créées durant le projet. Incitée par l'urgence de la pandémie et inspirée par le travail d'Étienne Wenger et d'autres sur le principe de la communauté de pratique, l'étude des auteures se penche sur la viabilité et l'efficacité du projet des communautés apprenantes entre pairs, sur leur rapport avec l'apprentissage tout au long de la vie et leur valeur pour offrir un soutien psychosocial. L'article s'achève sur une réflexion concernant l'utilité des communautés entre pairs pour les réformes afin d'assurer un apprentissage de qualité dans des situations de crise et plus globalement. 
ملخص

القيمة المكتسبة من خلال ممارسات مجتمعات التعلم أثناء جائحة كورونا - بعد توقف الدراسة وجهًا لوجه بسبب

تفشي الجائحة ، ومثل معظم أنظمة التعليم في جميع أنحاء العالم، تحولت المدارس والجامعات المصرية إلى التدريس عبر الإنترنت بنهاية شهر مارس 2020 وتم إعداد عدد قليل من المعلمين لتقديم دروسهم عبر الإنترنت بالإضافة إلى كيفية التعامل مع التوتر والقلق من الموقف. تعرض لنا هذه المقالة آراء مجموعة من المعلمين الذين اكتسبوا مؤخراً مهارات التعاون في مجتمعات الأقران من المتعلمين ، والتي أثبتت أنها مصدر فورى للدعم فى وقت الأزمة. وقد قام المؤلفون بتقديم نتائج دراسة سريعة قاموا بإجرائها في يونيو 2020 على عينة من 49 معلمًة من 17 مدرسة في مصر من المشاركين في مشروع الشراكة بين الجامعة والمدرسة للإصلاح والتنمية المهنية المستدامة الذي استمر من فبراير2017 إلى مارس 2020 ضمن المشروع، ونجح هؤلاء المعلمون بالفعل في إنشاء مجتمعات تعلم الأقران في 43 مدرسة مشاركة مع كليات التربية في ثلاث جامعات مصرية كبيرة. ويأتي مشروع الإصلاح، وهو مبادرة إراسموس +، و التي تم تنفيذها بتمويل من الاتحاد الأوروبي ، بعنوان "الشراكة بين الجامعة و المدرسة لمجتمعات المتعلمين الأقران" وبحلول مارس 2020، غير المعلمون المشاركون وبشكل كبير أساليب التدريس وثقافة المدرسة وهوياتهم وموقفهم تجاه مهنتهم، واستطاعوا أن يستمروا في التواصل مع أقرانهم في مجتمعات تعلم الأقران التي قاموا بإنشائها خلال المشروع. وفي إطار حالة الطوارئ هذه و مستوحى من عمل إتيين ونجر وآخرين في مجال مجتمعات الممارسة، تبحث الدراسة التي قام بها المؤلفون مدى استدامة وفعالية مشاريع مجتمعات تعلم الأقران وعلاقتها بالتعلم مدى الحياة وقيمتها في تقديم الدعم النفسي والاجتماعي. وتختتم المقالة بإلقاء الضوء على جدوى هذه المجتمعات للإصلاح التربوي وضمان جودة التعلم بشكل عام وكذلك في حالات الأزمات.

\section{Introduction}

In 2016, a project development team, which included all four authors of this article and was coordinated by the Middle East Institute for Higher Education, located at the American University in Cairo, set out to create an Egyptian-European peer community of learners through establishing a school-university partnership. While schools and universities in many European countries have a tradition of collaborating with each other, this was not yet the case in Egypt. Among other benefits, such collaboration is conducive to improving the quality of teacher education, and thus leads to improved education for their students, which in turn leads to better learning outcomes. Egypt has been in dire need of improving its quality of education 
for many years, and the current government has been planning a reform since $2016 / 2017$. Our aim in initiating the partnership project was to create a consultative forum which would support change in Egypt and share insights on the amount of detail and planning which a transformation of education in Egypt would entail. The project, co-funded by the ERASMUS+ programme of the European Union (EU), was called "the School University Partnership for Peer Communities of Learners" (SUP4PCL) and launched in 2017. ${ }^{1}$

Little did we know, when designing SUP4PCL in 2016, that by the end of the project implementation in March 2020, the world would be experiencing an unprecedented pandemic that would disrupt educational systems globally. Nor did we know that we were laying the foundations for a robust psychosocial support system for teachers and that we were indeed paving the way for teachers to become significant adult lifelong learners. We never once imagined that we would contribute to the resilience of our education system in times of crisis.

As we designed the SUP4PCL project, we were interested in enhancing the quality of reform and learning at the school and university levels in Egypt, as well as supporting current attempts at reform. What we were particularly interested in was a journey of cultural transformation and empowerment of teachers, educators and learners. We were eager to nurture leaders and agents of change in a dual fashion in both schools and faculties of education (FOEs) by creating Professional Development Schools (PDSs). This kind of partnership between universities and schools has been described by Linda Darling-Hammond as

an undertaking of schools and schools of education to create places in which entering teachers can combine theory and practice in a setting organized to support their learning; veteran teachers can renew their own professional development and assume new roles as mentors, university adjuncts, and teacher leaders, and school and university educators can together engage in research and rethinking of practice ... Ideally the university program and the school develop a shared conception of good teaching that informs their joint work (Darling-Hammond 2005, p.vii).

In the course of our SUP4PCL project, peer communities of learners (PCLs) were created as an accompanying strategy to strengthen this kind of dual reform, introducing mentorship and supporting inquiry along with reflection. With our project partners, we conducted case studies (e.g. Elhawary et al. 2020; Hammoud et al. 2020), which closely assessed and studied the created PCLs through various lenses, some of which were informed by the work of Etienne Wenger (1998). Other studies (e.g. Heggi et al. 2020; McCormack et al. 2020) made sure the PCLs met the main characteristics and purpose of such collaborative learning organisations using other frameworks developed by Kevin Patton et al. (2013).

The current article was inspired by the concept of value creation within the practice of social learning in a PCL over time (Wenger et al. 2011) and prompted by

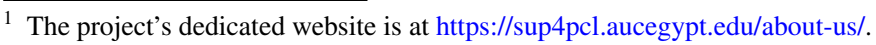


the emergency situation of the COVID-19 pandemic. In the section entitled "Background", we trace the history, the impact and the learning that occurred during the lifetime of the SUP4PCL project in a first instance. In the section entitled "School teachers and university educators during the pandemic", we then examine how these social learning structures were sustained and resurfaced during the COVID-19 crisis and how PCLs were able to create value.

\section{Background}

\section{The school-university partnership project}

Against a backdrop of growing concerns about global learning poverty (World Bank 2018), ${ }^{2}$ our project began with an expanded partnership among four Egyptian FOEs, four European FOEs from the United Kingdom, Ireland and Germany and 13 government public schools, which later expanded to 43 Professional Development Schools in Egypt. To understand the challenges and situation in 2016, we conducted baseline studies in Egypt, which confirmed the prevalence of difficult school and educational cultures. The main challenges revealed in the baseline reports concerned (1) the authoritarian culture of schools; (2) the absence of collaboration; and (3) a disempowered and unsupported teaching force. The project then moved on to implement several strategic initiatives to bring about change. A very significant initiative was the introduction of reciprocal mentorship between Egyptian and European faculty members at the university level, which was later extended to teachers in the schools. This strong, intense and regular mentorship led to the increased participation and learning of the teachers and the gradual introduction and creation of PCLs, within the European partner countries, across and within European and Egyptian institutions, and involving external stakeholders engaged in the reform process.

The project was conducted in two phases. During the first phase in 2017, 13 Egyptian government public schools were reached which we designated as "original" or "core" schools. Starting in 2018, during the second phase of the project, 30 additional schools were reached as each of the core schools reached out to two or more schools later designated as "cluster" schools. The total number of schools reached, whether through university mentorship alone or school and university mentorship together, were thus 43 schools. The cluster schools were regarded as a viable method of expansion and sustainability of the model. It is worth noting that the concept and practice of PCLs were not confined to the two types of schools and teachers therein, but actually spanned across the schools and the partner universities. Moreover, the FOEs also entertained and sustained their own PCLs.

\footnotetext{
${ }^{2}$ The World Bank defines learning poverty as meaning, "being unable to read and understand a simple text by age 10" (World Bank 2019).
} 


\section{The impact of the SUP4PCL project}

Observations and findings describing impact were made during the case studies conducted by various teams through the research described above. ${ }^{3}$ The creation and maintenance of PCLs resulted in deep change and new habits of thinking and learning. Collaboration, as opposed to competition, became the leading mode of learning and defined all relationships. Lifelong learning habits were acquired by many professionals. Deep individual and collaborative reflection strengthened introspection and both personal and professional growth. What seems obvious from the case studies is that a great deal of confidence and self-efficacy were acquired at both the school and university levels within the various collaborative teams.

The findings revealed that regular and sustained collaborative efforts led to multiple learning opportunities. The PCLs were being introduced to new concepts, such as Global Citizenship (GC), Sustainable Development (SD), and the integration of Science, Technology, Engineering, the Arts and Maths (STEAM). In addition, the PCLs were also mentored and introduced to innovative pedagogies, learner-centredness, Special Education Needs (SEN) and technologically enhanced learning and networking.

The project facilitated new modalities of learning particularly with regard to the integration of subject matter as well as the use of digital technology to enhance the learning and communication amongst the members of the various communities. In each of the participating Egyptian universities, a technology lab was established to support the learning of the PCLs. These laboratories were designated spaces with computers and other equipment for school teachers to be trained on the latest educational technology possibilities. Technology was now being used as a conduit for dialogue and for sharing innovative practices and news.

Cultural and personal changes were quite visible as school teachers and university educators grew closer to one another and to the students, became more intrinsically motivated, and manifested clear components of the self-determination and attachment theories that also had impacts on student learning. A sense of empowerment slowly emerged as the actors in the school and university institutions aspired to become true agents of change. Reflection and collaboration renewed teachers' sense of identity as active members of the teaching profession as they gained more competence in their teaching and learning. Teachers were for the first time introduced to reflection and research as part of their professional development. They also experienced a great deal of autonomy as they collaboratively designed and planned their classes through their newly acquired learning approach. Relational trust and rapport were instrumental in deepening the collaboration and learning experience. Trust was also important for the sustainability of the collaborative relationships. Sharing and caring became a well-established framing of the relationships emerging in most situations. From the central authorities to the local and school-based ones, there was a slow movement towards collaboration and the building of professional capital amongst university educators and school teachers. The results clearly laid

$\overline{3}$ The various case studies are available for download at: https://sup4pcl.aucegypt.edu/case-studies/. 
the foundations for psychosocial support for teachers who were gradually becoming lifelong learners.

\section{Teachers' psychosocial needs in a time of crisis}

On 11 March 2020, the World Health Organization officially upgraded the outbreak of COVID-19 to pandemic status (WHO 2020). By late April 2020, schools had shut down in 180 countries and $85 \%$ of students were out of school (World Bank 2020, p. 5). Parent involvement and home schooling have been on the rise as a result of the ongoing global pandemic COVID-19. ${ }^{4}$ In fact, in Egypt $100 \%$ of students were out of school at all levels. Final exams were cancelled for primary and preparatory schools. ${ }^{5}$ Teachers were directed to use Edmodo (an educational platform) to help in communication with their students and to the Egyptian Knowledge Bank (the national digital library) for obtaining material and resources. For assessment, the students were required to work on research projects and produce reports of their findings (Egypt Today 2020), while teachers were taken by surprise and needed support.

Most psychosocial guidelines, training and materials have targeted children and students in times of crises and emergency situations. The training of teachers has also mostly been for the purposes of equipping them to support their students. Not too much attention has been paid to the teachers' own needs, despite their very complex and challenging responsibilities often leading to burnout. According to insights emerging from self-determination theory (SDT), which conceptualises motivation, teachers do in fact have basic psychological needs that support the qualities of autonomy, competence and relatedness (Collie and Martin 2015). These qualities alleviate feelings of anxiety and anger that may accompany the profession in normal times and are very likely to be accentuated in crisis situations. The teachers participating in the SUP4PCL project had indeed gained a great deal of competence, had developed relations of trust and learning, and were experiencing a higher level of autonomy through collaborative learning. The advantages of being thus prepared for unexpected circumstances such as sudden school closures will become evident in the discussion of our study below.

Other studies point out that when teachers adopt effective child-centred learning strategies, both the teachers and the learners enjoy forms of well-being. Moreover, close student-teacher relations are good predictors for healthy behaviours and states of being (Spilt et al. 2011). One important strategy for building teacher resilience in times of crisis is employing participative education methods and introducing concepts such as peace-building and responsible citizenship. In addition, enhancing reflection, critical thinking, problem-solving and empathy also strengthen teacher resilience. Some of the most effective support to teachers comes from communities and their relationship with parents. Finally, availability of mobile technologies and messaging platforms is now

\footnotetext{
4 This article was drafted in August 2020.

5 The Egyptian school system comprises primary (6 years), preparatory (3 years) and secondary schools (3 years). Preparatory schools are lower secondary schools; their pupils are aged 12-15.
} 
also viewed as an important source of support for teachers (Ahmed 2017). It is important to point out that many of these sources of well-being (DoES Ireland 2020) were in fact integral results and components of the SUP4PCL project. Thus, those teachers who had been nurtured through the SUP4PCL project were already in an advantageous position when the COVID-19 pandemic broke out.

Recent literature on teacher support has focused on social and emotional learning (SEL), which underlines the importance of self-awareness, self-management, social awareness, relationship skills and responsible decision-making (Cipriano and Brackett 2020). Guidelines for well-being and self-care (e.g. DoES Ireland 2020) highlight the importance of relationships and the need to find alternative means to foster a sense of connectedness and belonging during times of isolation and remote work. Teachers are encouraged to ask for help from colleagues and should be supported when developing new skills to face the challenge of remote work (Duffield and O'Hare 2020).

\section{Theoretical framework}

\section{Value creation}

According to Wenger (Wenger et al. 2011), value is created when members of communities and/or networks are engaged in keeping up with their field of practice by learning together, sharing information, supporting each other with documents, tips and lived experiences to help solve challenges they confront as well as develop professionally. The value created can be of "immediate", "potential", "applied", "realized" and "reframed" use. ${ }^{6}$

Although largely inspired by Wenger's work, our methodology and the limitations of doing research under COVID-19 led us to rely more on "proxy indicators" (Wenger et al. 2011, p. 31) for the value created than on "personal and collective narratives" (ibid., p. 15). With regard to "immediate value", the study we present in this article was interested in how the knowledge these teachers gained in the past around the use of technology in teaching supported them in solving problems they came up against when obliged to go online during the pandemic. Their community created "potential value" for future use and "applied value" when using the skills and knowledge acquired in new contexts - in this case, school closures. Our study prompted the participants to reflect on the "realized value", their attainment of resilience and support, as an important goal leading them to consider new criteria for their success while teaching online, which is part of "reframed value".

\footnotetext{
${ }^{6}$ For definitions for each of these uses/values, see Wenger et al. (2011, pp. 19-21).
} 


\section{Research questions and methodology}

\section{Research questions}

Building on our above elaboration of the SUP4PCL project's history, aims and achievement, we next present the rapid study we conducted with 49 school teachers in 17 schools and 4 key informants from 3 FOEs. We were guided by the three following questions:

(1) Were the PCLs sustained during the COVID-19 crisis?

(2) Were they creating value to themselves and others?

(3) Were they a source of social and emotional support?

In our study, we used proxy indicators to determine how communities created value out of their social learning. One such proxy indicator of the value created was the frequency of their sustained communication, and another set of proxy indicators were the significant other functions fulfilled by the community particularly with regard to social and emotional support.

\section{Methodology}

Our research team for this study consisted of the four authors of this article, one of whom, Malak Zaalouk, acted as principal investigator. We conducted our rapid study from 9 to 15 June 2020, two months after the end of the SUP4PCL project (funding had lasted from January 2017 to 31 March 2020). Relying on and expanding the project case studies on school-university partnership which had resulted in the establishment of PCLs, our study sought to investigate the sustainability of these PCLs and whether they were still up and functioning during the COVID-19 pandemic lockdown in Egypt. Our study also aimed to identify how the PCLs managed to mitigate the various symptomatic emotions and behaviours that accompany crisis situations - such as anxiety, fear, loss of confidence, and isolation/loneliness - through their collaborative connections. To do so, we followed a mixed methods approach, collecting both quantitative and qualitative data through different instruments (Creswell 2012). We developed a teacher questionnaire, and we conducted interviews with key informants. The quantitative data of frequencies and percentages of the responses to the closed questions in the questionnaire provided the basis for a descriptive analysis. Qualitative data provided explanations for the various frequencies detected, and we analysed the qualitative data using thematic analysis. The questions we asked in the questionnaire and the interviews allowed us to identify proxy indicators, and the responses revealed the value creation achieved by the PCLs. All instruments and research methods went through ethical approvals, hence ensuring anonymity and confidentiality.

Participants in this study were school teachers representing a convenient sample. A total of 49 teachers willingly participated in our survey. Teachers from partner schools were contacted through the principal investigator and mentors from the FOEs partnering with the schools who asked for their willingness to participate in the study and 
School name:

(1) At your school, what is the status of PCL communication?

(2) We communicate:

$\begin{array}{ll}\square \text { daily } & \square \quad 2 \text { times per month } \\ \square \quad 2-3 \text { times per week } & \square \text { monthly } \\ \square \text { weekly } & \square \text { other }\end{array}$

(3) Which means of communication do you use for communication?

(4) Which means is used more frequently?

(5) PCL communication enhances your ability to meet professional requirements.

$\square$ strongly agree $\square$ agree $\square$ neutral $\square$ disagree

Please clarify the reason for your choice.

(6) PCL communications alleviate your feelings of anxiety.

$\square$ strongly agree $\square$ agree $\square$ neutral $\square$ disagree

Please clarify the reason for your choice.

(7) PCL communications alleviate your feelings of loneliness.

$\square$ strongly agree $\square$ agree $\square$ neutral $\square$ disagree

Please clarify the reason for your choice.

(8) PCL communications support you in building resilience.

$\square$ strongly agree $\square$ agree $\square$ neutral $\square$ disagree

Please clarify the reason for your choice.

Fig. 1 The English version of the teachers' questionnaire 
respond to the questionnaire. This sample of 49 school teachers from 17 schools were members of a larger group of SUP4PCL project participants from 43 Professional Development Schools that had partnered with three different Egyptian FOEs, namely those of Alexandria University, Ain Shams University and Helwan University. Judging from the original population from which the sample was selected, the majority were female, aged between 40 and 50. These teachers taught a variety of subjects, such as social sciences, languages and science subjects, across different grade levels (primary, preparatory and secondary). To ensure anonymity, we assigned a code to each teacher participant (T1, T2, etc.) for qualitative analysis of quotations from their responses.

In addition to the 49 school teachers, we also included 4 key informants representing project leaders from the three FOEs participating in our study. These were middle-aged females who had been mentors in our sample teachers' 17 Professional Development Schools during the lifetime of the SUP4PCL project as well as playing a leadership role in their project-related FOE teams. To collect their responses, we interviewed these key informants via e-mails and telephone calls, asking them two specific questions. In effect, they elaborated on the various aspects related to the three research questions guiding our study. They were specifically asked to describe the current status of the PCLs in their universities and their partner Professional Development Schools.

\section{Data collection and analysis}

As mentioned above, we collected our data using two main instruments. The first was a questionnaire for teachers designed to reflect the areas of focus in this study (see Figure 1). In developing the questionnaire (in English), we referred to research and previous studies related to PCLs (e.g. Lee and Lee 2018) and psychosocial aspects (NZMoH 2016) to identify the areas likely to be most affected by the pandemic lockdown. The questionnaire consisted of eight main questions divided into three sections. One section focused on PCL sustainability and frequency, the second traced professional value creation in PCLs, while the third focused on creating value in psychosocial aspects. The questions were formulated in such a way as to avoid leading the participants to any particular answer. Of these questions, one required teachers to select from a list of choices based on the frequency of occurrences, and four offered Likert-scale checkboxes (strongly agree/agree/neutral/disagree), generating quantitative data. These four questions were followed by blank spaces asking respondents to justify their selected response, which produced some qualitative data. The questionnaire was translated into Arabic to align with the participants' mother tongue to ensure clarity and was distributed electronically through Google Forms (a survey administration software) due to the lockdown.

With regard to the second instrument employed, two open-ended questions were asked of the four key informants online through e-mails and on the telephone. The first question concerned the status of the PCL in their faculty, while the second question asked about the PCL in the Professional Development Schools.

Teachers' responses were analysed quantitatively based on frequencies and percentages for all the closed-ended questions, including questions where teachers had 
to select from a list of options. As for the verbal responses where teachers justified and clarified their selected responses, these were analysed using thematic analysis. This involved developing a preliminary list of themes which we discussed and reworded upon reaching consensus. We assigned a code word or phrase that accurately described the core idea in each of the responses. Finally, we applied lean coding, in which we assigned only a few codes that were directly related to the focus of our study and reflected in the questionnaire. Consequently, several themes were generated, conveying teachers' various perspectives. As for the interview responses from the key informants, we also analysed these qualitatively through thematic analysis (Creswell 2012).

\section{School teachers and university educators during the pandemic}

With the onslaught of the COVID-19 emergency, the SUP4PCL project team found itself facing a golden opportunity to test the extent to which the results and findings generated over the past three years of intervention were helping in the mitigation of the crisis. Hence, we were curious to investigate to what extent the PCLs in the various schools were sustained during the pandemic. Moreover, we also wished to learn from the teachers, educators and other stakeholders how they benefited from their connectivity and collaboration during lockdown. Finally, we were particularly interested to discover to what extent the various symptomatic emotions and behaviours that are known to accompany crisis situations, such as anxiety, fear, loss of confidence and isolation/loneliness were effectively mitigated by the PCLs' collaborative connections. Thus, our team formulated the three research questions mentioned above; the first around sustainability, the second around the benefit from being in a PCL and lastly the psychosocial support the PCL was able to provide to participants.

\section{Findings from the teacher responses}

We present our findings from our rapid study in three sections, one for each research question. The first section describes the findings related to PCLs' sustainability including frequency and modality of communication. The second section presents the findings related to the value created by being part of a PCL. The third section covers findings related to teachers' mitigation of crisis-related psychosocial symptoms. It explains the methods participants used for overcoming feelings of anxiety and loneliness, and finally for building resilience.

\section{Research question 1: Sustainability of PCLs}

The school teachers' answers to the questionnaire revealed that around $91.5 \%$ of them sustained their PCL communication during the COVID-19 pandemic. The fact that members of the learning community chose to sustain the communication serves in our study as a proxy indicator of the value it added to their lives. Around two thirds of 
the teachers asserted that they communicated with other PCL members either daily or up to three times per week, while roughly one third (27\%) indicated that they communicated either weekly or two times per month. Clearly, this communication was not only sustained, but actually became more frequent again during the pandemic, supporting the value experienced by members of the community. During the lifetime of the SUP4PCL project, teachers had developed technological skills which made it easier for them to communicate digitally amongst themselves and with their students. When the SUP4PCL team conducted a needs assessment in 2017, before the launch of the project, we found that teachers lacked the experience of integrating technology into their teaching and learning. Hence, technological skills were prioritised among the main topics discussed in PCLs during the lifetime of the project (Elhawary et al. 2020; Hammoud et al. 2020; Heggi et al. 2020; McCormack et al. 2020; Zaalouk et al. 2020). To further add to the challenge confronting Egyptian teachers, with the outbreak of the pandemic, the Ministry of Education and Technical Education (MOETE) obliged them to use Edmodo and Microsoft Teams as educational platforms to connect with other teachers and with students. Despite the formal termination of the SUP4PCL project's activities, participant teachers willingly chose to sustain their PCLs for support during the pandemic. Although MOETE offered online training for teachers on the use of technology, project participants voluntarily chose to communicate with their PCL and to resort to their university mentors for support.

In terms of the preferred modes of communication utilised, teachers used a variety of technological applications which they had largely used and acquired during the SUP4PCL project, such as WhatsApp, Edmodo, Microsoft Teams, Messenger and Zoom. However, our findings revealed that almost $63 \%$ of our sample school teachers frequently resorted to using WhatsApp as their main means of communication. The teachers' decision to sustain the PCL beyond the duration of the project, and the intensity of the communication - increased after the onset of the pandemic - can be regarded as a proxy indicator of the value created through these particular communities (Wenger et al. 2011).

\section{Research question 2: PCL professional benefits as value created}

The majority (94\%) of our 49 participants strongly agreed or agreed that the PCLs in their schools were helping them meet their professional requirements during the pandemic. However, one participant, accounting for $2 \%$, did not feel that the PCL communications helped him/her develop their professional requirements because of his/her inability to use technology, while two respondents (4\%) remained neutral.

Through thematic analysis of all teachers' verbal clarifications of why they checked a particular box in the questionnaire, one common theme which emerged was continuous professional development (CPD). Clearly, PCL communication created value by providing various CPD opportunities, regarded as the core of lifelong learning. Several participants stated that they felt that PCL communication supported ongoing activities and positive interactions between teachers and students during the pandemic through the exchange of expertise. Teachers were challenged in their attempt to communicate with students and needed tips. Through deeper analyses of the responses it 
appeared that teachers' various exposures to lifelong learning opportunities seemed to help develop their knowledge related to everyday teaching practices and content areas. In this regard, they aimed at developing their professional and technological skills by filling their knowledge gaps. As stated by most of our respondents, this occurred through exchanging and sharing information, experiences and expertise in matters related to the latest trends in the educational field. For example, participants clarified that through PCL communication, they were directed to online training opportunities. Other participants added that the PCL helped a lot in keeping abreast of the latest educational developments at the policy level. One respondent stated that

"keeping pace with the fast flow of information from the central Ministry of Education requires PCL communication" (T20). ${ }^{7}$

Furthermore, PCL communication helped these teachers reflect on their strengths and weaknesses. Consequently, reflection led many of them to modify their future plans. For instance, some decided to further develop their research skills to adapt to the current situation.

With regard to teachers' technological abilities, PCL communication aided them in overcoming barriers and solving immediate problems. They developed their skills to use various technological applications, such as Edmodo and Microsoft Teams. One participant highlighted that

"PCLs help us overcome some obstacles that we face while performing some tasks, such as correcting online exams, or being unable to access the ministry site" (T9).

The teachers reflected that PCLs helped them

"gain experience in how to deal with the Edmodo programme, especially in our communication with students" (T19).

Additionally, our respondents stated that PCLs helped them

"prepare educational videos of the national curriculum and upload them on YouTube to satisfy the objectives of education during COVID-19 as well as create virtual classrooms using Google Classroom" (T19).

During the COVID-19-related school closures, the Edmodo and Microsoft Teams applications had been put forward by MOETE as platforms to be used by teachers to go online and communicate with their students during lockdown. MOETE released a new set of rules and regulations to be followed by the teachers (El Zayat 2020). They emphasised to teachers and students the importance of using the Egyptian Knowledge Bank (EKB), which is the national digital library that provides access to learning resources (ibid.). Additionally, MOETE required that teachers assess their students through research projects and papers as opposed to the traditional physical paper-based examination system in Egypt. In many cases, teachers struggled as they

7 All participants' responses quoted here were translated into English for the purposes of this article. 
were neither trained to use these technological applications nor fully able to follow these regulations. Hence, the majority of the conversations between PCL members were conducted in an attempt to clarify these new directives and to support each other. One participant declared that

"the PCL members support each other in understanding the new assessment methods, set by the MOETE, and in explaining to the students how to write the assigned research papers" (T1).

The fact that teachers wished to master the new applications indicates that they were keen on supporting their students' learning by helping them understand their tasks more effectively. For example, the participants supported each other in learning how to use Microsoft Teams, as requested by MOETE, in order to support their students. As an outcome of their technological development, teachers were able to discuss with students methods of writing research papers and inform students on the modality of submission (physically or online). ${ }^{8}$ Teachers further searched for more online CPD opportunities by expanding their PCLs. In this respect, one of the participants said that they had started to

"contact different groups of teachers and benefit from the experiences of others" (T42).

Thus, this kind of PCL communication created value for the community and helped teachers to expand their knowledge and technological abilities, which, in turn, helped them to continuously develop professionally and support students' learning.

\section{Research question 3: Psychosocial needs}

\section{Alleviating feelings of anxiety}

A significant number (92\%) of our 49 participants strongly agreed or agreed that the PCLs in their schools alleviated their feelings of anxiety in this challenging time. Nevertheless, three teachers $(6 \%)$ did not regard PCL communication as a means for alleviating their feelings of anxiety, while one participant (2\%) remained neutral.

The first common theme emerging from our thematic analysis of teachers' verbal clarifications was that their PCL communication provided them with the opportunity to develop their knowledge. As many of them stated, their anxiety was alleviated by being better informed and in control of their surroundings. For instance, one participant explained that

"not knowing causes anxiety, tension, and fear of the unknown" (T8).

Therefore, some of them stressed the positive impact of being aware of public health issues and of "knowing the latest methods for maintaining public health" (T38).

\footnotetext{
${ }^{8}$ Given the evident digital divide, students were allowed to submit either online or physically at school.
} 
Proactively, PCL communication supported them emotionally and psychologically, which we identified as a second common theme. In that sense, they exchanged and shared information, experiences and knowledge, for example when exchanging "information about the causes of anxiety" (T31). Consequently, they also dispelled worrying rumours which they encountered on social media. This helped the teachers in eliminating their fears of getting infected and in overcoming their feelings of isolation. For instance, one teacher elucidated:

"Communication helps us feel safe and that we are not alone. There is always support even in matters other than work and personal assistance" (T25).

Additionally, PCL communication created an atmosphere of intimacy and affection which supported "building a spirit of optimism and hope" (T26).

As an outcome of their knowledge development as well as the emotional and psychological support, teachers were able to communicate effectively with their students. As one respondent clarified,

"It helps a lot, because communication makes the student and the teacher feel closer, so the student stops feeling concerned because there are many ways to help them learn and excel" (T40).

Consequently, when teachers and students get closer, this positively impacts their psychosocial well-being (Milatz et al. 2015). Finally, PCL communication helped teachers feel empathy toward each other by "giving the team reassurance and identifying our needs" (T32).

\section{Alleviating feelings of loneliness}

Ninety per cent of the 49 teachers strongly agreed or agreed that PCLs had an impact in terms of reducing the feeling of loneliness. Two participants (4\%) did not consider PCL communication a means for alleviating their feeling of loneliness without any further clarifications, while three respondents (6\%) remained neutral.

When teachers were asked to clarify the reasons for checking a box under this particular question, their responses varied, with two main themes emerging from our thematic analysis. The first common theme was the teachers' belief that PCL communication helped build social relationships. They used this channel not only to tackle general topics but also discussed personal topics. Amidst the COVID-19 pandemic, these teachers managed to develop a strong bond with each other and sustain their relationships in this challenging time, as one participant explained,

"It helps in sustaining social relationships, between my colleagues and I" (T11).

This led to increasing teachers' sense of relatedness, which increased their intrinsic motivation to "create a bond between team members with shared goals, and form friendships" (T32). E-communicating through groups helped the teachers build strong social relationships. Evidently, one participant clarified that 
"creating virtual communities by using social communication sites leads peo-

ple to reduce the feeling of isolation" (T23).

As a second theme explaining their positive responses, the teachers mentioned mutual support. They managed to support each other emotionally and psychologically. Teachers concurred that PCL communication reduced their sense of isolation and their feeling of anxiety and stress. To clarify, one teacher narrated that

"It helps a lot because of the feeling that you are in a closed place and disconnected from others which then makes you feel fearful and distressed. We are together even when each person is at home because we always communicate. Despite the slogan 'Stay at Home', we are always together" (T25).

Thus, effective communication helped teachers to feel like they were "one big family", as elaborated by one of the participants. They added that indulging in communication helped in overcoming the feeling of loneliness.

\section{Building resilience}

Focusing on the "strongly agree" and "agree" responses, we found that $90 \%$ of the participants viewed PCL communication as a very effective tool to build resilience during COVID-19. However, two participants (4\%) did not view PCL communication as an effective tool and three $(6 \%)$ remained neutral.

It emerged from teachers' responses that effective communication positively impacted on the strength of their relationships. In this respect, one participant said that PCL communication pushed them to significantly help each other. This happened through exchanging and sharing information. The teachers shared their experiences as a step towards supporting others to overcome the challenges they found themselves facing, as one participant explained: "Through the PCL and exchanging experiences, new methods of solving problems or overcoming difficulties are presented" (T23). This is confirmed in another participant's statement that

"sharing the challenges that each school is facing, and how it is able to overcome them, helps others to find the best solution that suits their circumstances" (T49).

Moreover, PCL communication helped teachers build "tolerance for increased psychological and emotional pressure" and helped them" benefit from shared experiences" (T22), as explained by one participant. It further helped them to release the tension and pressure that they continue to feel during this difficult time. As expressed by one of the participants,

"communication helps us overcome many of the difficulties that we encounter at work. Also, it helps in freeing ourselves and relieving tension, which occurs from the successive events around us" (T25).

Thus, it gives them positive energy to build resilience and to learn how to address problems together. 


\section{Findings from key informants at the FOE Level}

Three themes emerged from our analyses of the key informant responses: (1) the status of the PCL at the FOE level; (2) the status of the PCL at the Professional Development Schools level; (3) the relationship between the FOE and the partner schools.

Our four key informants agreed that their FOE PCLs were sustained and strengthened by university-related professional and social connections. On the professional level, they were discussing innovative research ideas, mostly around qualitative research. Moreover, they shifted from face-to-face teaching to an online teaching mode. Technical support was provided on how to utilise platforms, such as Google Classroom and Microsoft Teams, and how to troubleshoot problems with students. Invitations to attend workshops on using technology were extended amongst PCLs and offered by members of the PCLs themselves. Furthermore, PCLs expanded to other faculties, such as the Faculty of Medicine at Helwan University, which organised the first online seminar on the COVID-19 pandemic in collaboration with Martin Luther University in Halle-Wittenberg, Germany (which had been the twin partner of Helwan University during the ERASMUS+ project) and Halle University Hospital.

On the social level, PCL members supported each other on aspects that went beyond their profession. They provided each other with medical advice, e.g. discussing matters related to COVID-19. Moreover, their social interactions helped them support each other emotionally. Finally, they were keen to sustain their close relationships by exchanging greetings on special occasions, amidst the lockdown.

Our key informants affirmed that the PCLs inside schools supported each other by sharing tips regarding online communication with students and instructions from MOETE. They further shared with each other online resources, books and other materials related to teaching and learning, using Zoom and WhatsApp.

The various PCLs between faculty members and school teachers were sustained during the lockdown. The FOEs helped teachers overcome technological obstacles by providing them with technical support on utilising the Edmodo and Google platforms, and the Egyptian Knowledge Bank (EKB). It was clear that the partnership established between the FOEs and schools through PCLs allowed for a strong and secure connection where teachers resorted back to FOE mentors for constant consultations on daily issues they came up against during the pandemic.

In conclusion, as stated by a university faculty member, "Our biggest success is that the school teachers have noticed that the university faculty is constantly supporting them."

\section{Conclusions}

From the above findings, it is clear that both teachers and faculty members were engaged in creating value and experienced great benefits from sustaining their PCLs during the pandemic. What emerged from the teachers' responses as the four areas where they benefited most were (1) knowledge development/exchange (which included both professional knowledge and other general administrative or medical 
types of information); (2) continuous professional development (which included good practices and tips on how to deal with online teaching and subject matters); (3) relationship with students; and (4) evolving social relationships/emotional support and or bonding. These relationships had been nurtured over time. The very small number of those who did not see a clear benefit suggests an expected divide amongst those who were capable of mastering technology and those who were not (due to many possible factors such as age, socio-economic background and attitude). Although there are no recent official data on the digital divide in Egypt, this would be an interesting topic for future research.

Our key informants highlighted similar results for the university FOE faculty members. It is clear that they also benefited from the previously formed PCLs, both at the FOE level and in their work with their partner schools. Observing the evolution of the PCLs in schools, they attested to the continued bond between their faculties and the partner schools.

Hence, one can safely conclude that our study found that value was created for three types of audiences (1) the teachers; (2) their students; and (3) the faculty members at universities. Moreover, the learning that took place in the past during the lifetime of the project and in the current situation, confirmed a perspective where both long-term and short-term values were created (Wenger et al. 2011).

What is certain is that the relationships and communication within the PCLs seem to provide what the literature and general wisdom for handling crisis situations offer as best advice to teachers. Most of the literature emphasises the importance of the relational aspect and the sense of community for alleviating anxiety, fear, loss of confidence and feelings of isolation (Ahmed 2017; UNRWA 2013). The literature also advises teachers to keep connected, to ask for help when they need it and to be very reflective and aware of the stages they go through. Empathy is extremely valuable in such situations. Moreover, much of the psychosocial support and good practices emphasise the role of community and the need to remain in touch with students.

Interestingly, our study revealed that the PCLs not only supported the teachers in schools amongst each other, but in addition the teachers referred back to their university mentors for advice within the cross-institutional partnership PCL, particularly with regard to online competencies. The university PCL members also sustained their relationships within their own faculties, which proved to be a blessing for mutual peer support as they turned to online teaching with no prior institutional support. Both types of PCLs also went beyond their usual boundaries and extended their services to other communities. Thus, one important conclusion in answering the three research questions which guided our study is that PCLs definitely helped (and are, indeed, still helping) teachers to meet the challenges of a crisis.

Returning to the original purpose of the SUP4PCL project, the second important conclusion is the confirmation that putting in place good practices for quality lifelong learning bodes very well for laying the foundations for reform, and creating the conditions for change. Clearly, those conditions are the very same conditions for the kind of quality collaborative learning needed for confronting crisis situations. If quality is in place, we can be assured that education in times of crisis and emergencies will be possible. Interestingly, the PLCs' strategies we have presented are also 
truly cost-effective, which is quite a relevant aspect during the current dual crises of health and finance. Emotional support, empathy and peer learning are human traits that do not cost much in financial terms.

The numerous research studies that show the relevance of PCLs to teacher empowerment and student advancement (e.g. Patton and Parker 2017; Zaalouk et al. 2020), combined with the new dimensions added by our own findings from the current study, encouraged us to develop a set of recommendations. We have submitted these to Egyptian policymakers, offering evidence-based advice to provide enabling environments for PCLs to be created, sustained and mainstreamed across both pre-university and university education levels. Two of the main challenges that had emerged clearly from the studies conducted during the lifetime of the SUP4PCL project were the dearth of time and official recognition of the practice of PCLs. Therefore, one of the recommendations we put forth to the Egyptian government is to explicitly allow teachers and educators the necessary time for their own CPD as part of their official workloads.

Time in and of itself however was discovered to be insufficient in some of the significant in-depth studies (e.g. Turner 2015) to create the desired learning and transformation. Leadership and mentorship for direction are also required. Institutional leadership can be sought in partner universities, in school-based instructional leadership and/or at the district level. For leadership and mentorship to be sustained within and across institutions, a system of incentivisation is deemed necessary. Recognising the leadership and mentorship efforts for the identification of domains of expertise for PCL activities can take many forms, including building such accomplishments into recognised pathways to professional promotions and academic recognition. Structural support is also important, since the practice may require some resources. Wenger clearly outlines three such "enabling structures that integrate the work of communities of practice" into organisations striving to mainstream knowledge acquisition, management and practice through PCLs: sponsorship, recognition and support (Wenger 2004). Therefore, another recommendation we offered to policymakers is for them to establish within and across institutions the structures that would oversee the proper coordination between schools and universities. Such structures straddling university and pre-university institutions would ensure that school-university partnerships are sponsored, supported and recognised as genuine foundations of collaborative knowledge and practice, as well as being catalysts for reform.

\section{References}

Ahmed, H. (2017). Approaches to providing psychosocial support for teachers and other school staff in protracted conflict situations. Knowledge, Evidence, and Learning for Development (K4D) helpdesk report. Brighton: Institute of Development Studies. Retrieved 5 May 2020 from https://assets. publishing.service.gov.uk/media/5bacd290ed915d25a8b3b676/117__119_-_Psychosocial_suppo rt_for_teachers_and_other_education_staff_-_Final.pdf.

Cipriano, C., \& Brackett, M. (2020). Teacher, interrupted: Leaning into social-emotional learning amid the COVID-19 crisis. EdSurge, 18 March [online article]. Retrieved 10 February 2021 from https:// 
www.edsurge.com/news/2020-03-18-teacher-interrupted-leaning-into-social-emotional-learn ing-amid-the-covid-19-crisis.

Collie, R. J., \& Martin, A. J. (2015). Teachers' psychological needs, motivation, and autonomy support: Impacts on students' growth goals and achievement outcomes. In B. Higgins (Ed.), Goal setting and personal development: Teachers' perspectives, behavioural strategies and impact on performance (pp. 1-14). Hauppauge, NY: Nova Science Publishers.

Creswell, J. W. (2012). Educational research: Planning, conducting and evaluating quantitative and qualitative research (4th ed.). Boston, MA: Pearson Education.

Darling-Hammond, L. (2005). Developing professional development schools: Early lessons, challenge, and promise. In L. Darling-Hammond (Ed.), Professional development schools: Schools for developing a profession (pp. 1-27). New York, NY: Teachers College Press.

DoES Ireland (Department of Education and Skills, Ireland). (2020). Teacher wellbeing \& self-care during the COVID-19 (Coronavirus) school closures. Dublin: Department of Education and Skills. Retrieved 10 February 2021 from https://assets.gov.ie/73304/e775d30a17114eaa89029be25fecd196. pdf.

Duffield, S., \& O'Hare, D. (2020). Teacher resilience during coronavirus school closures. Advice series, 7 April. Leicester: The British Psychological Society. Retrieved 10 February 2021 from https://www. bps.org.uk/sites/www.bps.org.uk/files/Member\%20Networks/Divisions/DECP/Teacher\%20resilien ce\%20during\%20coronavirus\%20school\%20closures.pdf.

Egypt Today (2020). Egypt cancels final exams for primary, preparatory grade students due to Coronavirus. Egypt Today, 20 March [online article]. Retrieved 11 July 2020 from https://www.egypttoday. com/Article/1/82822/Egypt-cancels-final-exams-for-primary-preparatory-grade-students-due.

Elhawary, D., O’Shea, A, Underwood, J., Elkharashi, S., Hammoud, D E, \& Elkhaial, N.H (2020). Leading change through peer communities of learners: A Case Study between Egypt and the United Kingdom. SUP4PCL case study. Alexandria/ Northampton: Alexandria University/University of Northampton. Retrieved 10 February 2021 from https://sup4pcl.aucegypt.edu/wp-content/uploads/ 2020/04/Capacity-Building-SUP4PCL-Case-Study-Alexandria-University-and-University-of-North ampton.pdf.

El Zayat, N. (2020). Egypt: K-12 Egyptian Knowledge Bank study portal and new form of assessment, Education continuity stories series. Paris: OECD Publishing. Retrieved 22 February 2021 from https://oecdedutoday.com/wp-content/uploads/2020/08/Egypt-Knowledge-Bank-Study-Portal.pdf.

Hammoud, D.H., Elkomy, M.M., Abdulgawad, E.E., Elhawary, D., Makram, D., Elkharashi, S., Elghanam, S.M., Elkhaial, N.H., Ragheb, R.A., \& Alshamy, A. (2020). A journey of transformation: The case study about Alexandria University's partnership with schools to build peer communities of learners. SUP4PCL case study. Alexandria: Alexandria University. Retrieved 10 February 2021 from https://sup4pcl.aucegypt.edu/wp-content/uploads/2020/04/Capacity-Building-SUP4P CL-Case-Study-Alexandria-Universitys-Schools.pdf.

Heggi, A.I., Elsayed, M.M., Ghonem, A.M., Shehab, L.M., \& Morsy, H.K. (2020). The Evolution of peer communities of learners (PCLs) at Helwan University and its impact on the transformation of professional learning practice. SUP4PCL case study. Cairo/Halle-Wittenberg: Helwan University/Martin Luther University. Retrieved 10 February 2021 from https://sup4pcl.aucegypt.edu/wp-content/ uploads/2020/04/Capacity-Building-SUP4PCL-Case-Study-Helwan-University-and-Martin-LutherUniversity.pdf.

Lee, D. H. L., \& Lee, W. O. (2018). Transformational change in instruction with professional learning communities? The influence of teacher cultural disposition in high power distance contexts. Journal of Educational Change, 19(4), 463-488. https://doi.org/10.1007/s10833-018-9328-1.

McCormack, O., Tannehill, D., O’Gallchoir, C., Young, A., Kamal, R., \& Barsoum, H. (2020). The development of a professional learning community within Ain Shams University, Cairo. SUP4PCL case study. Cairo/Limerick: Ain Shams University/University of Limerick. Retrieved 10 February 2021 from https://sup4pcl.aucegypt.edu/wp-content/uploads/2020/04/Capacity-Building-SUP4P CL-Case-Study-Ain-Shams-University-and-University-of-Limerick.pdf.

Milatz, A., Lüftenegger, M., \& Schober, B. (2015). Teachers' relationship closeness with students as a resource for teacher wellbeing: A response surface analytical approach. Frontiers in Psychology, 6, Art. 1949. http://dx.doi.org/10.3389/fpsyg.2015.01949.

NZMoH (New Zealand Ministry of Health) (2016). Framework for psychosocial support in emergencies. Wellington: Ministry of Health. Retrieved 10 February 2021 from https://www.health.govt.nz/ system/files/documents/publications/framework-psychosocial-support-emergencies-dec16-v2.pdf. 
Patton, K., Parker, M., \& Pratt, E. (2013). Meaningful learning in professional development: Teaching without telling. Journal of Teaching in Physical Education, 32(4), 441-459. https://doi.org/10.1123/ jtpe.32.4.441.

Patton, K., \& Parker, M. (2017). Teacher education communities of practice: More than a culture of collaboration. Teaching and Teacher Education, 67, 351-360. https://doi.org/10.1016/j.tate.2017.06. 013.

Spilt, J. L., Koomen, H. M. Y., \& Thijs, J. T. (2011). Teacher wellbeing: The importance of teacherstudent relationships. Educational Psychology Review, 23(4), 457-477. https://doi.org/10.1007/ s10648-011-9170-y.

Turner, C. J. (2015). Impact of professional learning community design on teacher instruction. Unpublished Doctoral Dissertation. University of Arkansas, Fayetteville, AR. Retrieved 10 February 2021 from https://scholarworks.uark.edu/cgi/viewcontent.cgi?article $=1009 \&$ context $=$ etd.

UNRWA (United Nations Relief and Works Agency for Palestine Refugees in the Near East) (2013). Psychosocial support for education in emergencies: Training and resource package for teachers and counsellors. Bayader Wadi See: UNRWA. Retrieved 2 March 2021 from https://www.unrwa.org/ sites/default/files/3.2_unrwa_pss_for_education_in_emergencies_training_packagefinaljune.pdf .

Wenger, E. (1998). Communities of practice: Learning, meaning, and identity. Cambridge University Press. https://doi.org/10.1017/CBO9780511803932.

Wenger, E. (2004). Knowledge management as a doughnut. Ivey Business Journal, January/February [online article]. Retrieved 15 July 2020 from http://iveybusinessjournal.com/publication/knowledgemanagement-as-a-doughnut/.

Wenger, E., Trayner, B., \& De Laat, M. (2011). Promoting and assessing value creation in communities and networks: A conceptual framework. Rapport 18. Heerlen: Open Universiteit Nederland, Ruud de Moor Centrum. Retrieved 10 February 2021 from https://www.asmhub.mn/uploads/files/11-04wenger-trayner-delaat-value-creation.pdf.

WHO (World Health Organization) (2020). Director-General's opening remarks at the media briefing on COVID-19 - 11 March 2020. WHO, 11 March [webnews]. Geneva: World Health Organization. Retrieved 15 February 2021 from https://www.who.int/director-general/speeches/detail/who-direc tor-general-s-opening-remarks-at-the-media-briefing-on-covid-19_11-march-2020.

World Bank (2018). World Development Report 2018: Learning to realize education's promise. Washington, DC: World Bank. Retrieved 10 February 2021 from https://www.worldbank.org/en/publication/ wdr2018.

World Bank (2019). Learning poverty. World Bank Brief, 15 October [online brief]. Washington, DC: The World Bank. Retrieved 15 February 2021 from https://www.worldbank.org/en/topic/education/ brief/learning-poverty.

World Bank (2020). The COVID-19 pandemic: Shocks to education and policy responses. Washington, DC: World Bank. Retrieved 10 February 2021 from https://openknowledge.worldbank.org/bitst ream/handle/10986/33696/148198.pdf?sequence=4\&isAllowed=y.

Zaalouk, M., El-Deghaidy, H., Ramadan, L., Sabbah, D., \& Eid, L.(2020). School-University partnership: Process, structure, outcomes and impact. Cairo: Middle East Institute for Higher Education at the American University in Cairo. Retrieved 10 February 2021 from https://sup4pcl.aucegypt. edu/wp-content/uploads/2020/04/SUP4PCL-Partnership-Case-Study-The-Middle-East-Institute-forHigher-Education.pdf.

Publisher's Note Springer Nature remains neutral with regard to jurisdictional claims in published maps and institutional affiliations.

Malak Zaalouk PhD, is Professor of Practice and the Founding Director of the Middle East Institute of Higher Education, at the American University in Cairo.

Heba EL-Deghaidy PhD, is currently Chair of the Department of International and Comparative Education at the School of Humanities and Social Sciences, American University in Cairo.

Lamiaa Eid is a researcher at the Middle East Institute of Higher Education, at the American University in Cairo. 
Lujain Ramadan worked as a researcher at the Middle East Institute of Higher Education, at the American University in Cairo (June 2017-September 2020). She currently works for the United Nations Development Programme (UNDP).

\section{Authors and Affiliations}

\section{Malak Zaalouk ${ }^{1} \cdot$ Heba EL-Deghaidy ${ }^{\text {· Lamiaa Eid }}{ }^{1} \cdot$ Lujain Ramadan $^{1}$}

Heba EL-Deghaidy

h.eldeghaidy@aucegypt.edu

Lamiaa Eid

lamiaafathy@aucegypt.edu

Lujain Ramadan

lujain@aucegypt.edu

1 Middle East Institute for Higher Education, American University in Cairo, Cairo, Egypt 